\title{
GENETIC DIVERSITY AND STRUCTURE OF LATVIAN TILIA CORDATA POPULATIONS
}

\author{
Dainis Edgars Runğgis ${ }^{\#}$ and Baiba Krivmane \\ Latvian State Forest Research Institute "Silava", 111 Rïgas Str., Salaspils, LV-2169, LATVIA \\ \# Corresponding author, dainis.rungis@silava.Iv
}

Contributed by Dainis Rung̣is

\begin{abstract}
Changing climatic conditions are transforming the ecological and silvicultural roles of broadleaf tree species in northern Europe. Small-leaved lime (Tilia cordata Mill.) is distributed throughout most of Europe, and is a common broadleaf species in Latvia. This species can tolerate a broad range of environmental and ecological conditions, including temperature, water availability, and soil types. The aim of this study was to assess the genetic diversity and differentiation of Latvian T. cordata populations using nuclear microsatellite markers developed for Tilia platyphyllos. After testing of 15 microsatellite markers, Latvian T. cordata samples were genotyped at 14 microsatellite loci. Latvian T. cordata populations had high genetic diversity, and were not overly isolated from each other, with moderate gene flow between populations. No highly differentiated populations were identified. Vegetative reproduction was identified in most analysed populations, and almost one-third of analysed individuals are of clonal origin. T. cordata has high timber production potential under the current climatic and growth conditions in Latvia, and therefore this species has potential for use in forestry, as well as playing a significant role in maintaining biodiversity and other ecosystem services.
\end{abstract}

Key words: small-leaved lime, microsatellite markers, clonal reproduction, forestry, climate change.

\section{INTRODUCTION}

Changing climatic conditions are also transforming the role of broadleaf tree species in northern European forests. There is also increasing interest in these species from a silvicultural aspect. Small-leaved lime (Tilia cordata Mill.) is found throughout most of Europe, except for northern Scandinavia. The distribution of this species in Northern Europe is strongly influenced by temperature, and correlates with the annual isotherm of $+2{ }^{\circ} \mathrm{C}$ and July isotherm of $+17^{\circ} \mathrm{C}$ (Piggot and Huntley, 1978; Piggot and Huntley, 1980). T. cordata is a shade tolerant species, often forming the second storey in forest stands, and is frequently found in the understorey. $T$. cordata successfully regenerates in stands where the dominant species is $T$. cordata, thus ensuring the continuity of these stands. In general, $T$. cordata tolerates short-term water deficit, but summer drought conditions limit the southern distribution of this species in the Mediterranean region (Radoglou et al., 2009). T. cordata is tolerant of both high and low temperatures, and temperatures of over $15{ }^{\circ} \mathrm{C}$ are required during the growing season to ensure successful production of fertile seeds (De Jaegere et al., 2016). However, vegetative reproduction is common in this species, with sprouts forming after coppicing and from trunks and branches in contact with the soil (Erichsen et al., 2019). In a study of 27 populations of both $T$. cordata and T. platyphyllos in the UK, approximately $25 \%$ of individuals were found to be a result of clonal reproduction (Logan et al., 2015).

T. cordata is a common broadleaf species in Latvia, found in all regions. The largest areas of both pure and mixed stands, are found in Eastern Latvia - Augšzeme (730.2 ha, $17.5 \%$ of the total stand area), Aiviekste region (623.5 ha, $15.0 \%)$, Gaujaszeme (518.4 ha, 12.4\%) and South Vidzeme (488.2 ha, $11.7 \%$ ). Less than $10 \%$ of the total area of T. cordata stands are located in other regions of Latvia. T. cordata stands are mainly found in nutrient-rich or eutrophic dry forest types - Aegopodiosa, Oxalidosa, Hylocomiosa and Mercurialiosa mel. ( $91.8 \%$ of the linden area). T. cordata stands do not occur in nutrient-poor forest growth conditions. Pure and mixed $T$. cordata stands are productive in 
good growing conditions, with stand volume up to $100 \mathrm{~m}^{3}$ in age class $1\left(1-20\right.$ years) and up to $327-502 \mathrm{~m}^{3} \cdot \mathrm{ha}^{-1}$ in age classes 4 (61-80 years) and 5 (81-100 years), and while the productivity of $T$. cordata plantation forest stands is highly dependent on the soil type, is was concluded that $T$. cordata is a suitable tree species for plantation forestry in Latvian climatic conditions (Daugaviete et al., 2019).

There is a paucity of molecular genetic resources for use in study of $T$. cordata. Some previous studies have utilised isozyme markers (Maurer and Tabel 1995; Fromm and Hattemer 2003), and RAPD markers have also been utilised to investigate phylogenetic relationships of Tilia species (Liesebach and Sinkó, 2008). However, these marker systems are hampered by technical difficulties, including poor resolution and reproducibility. Microsatellite markers are widely used for population genetic studies due to their high levels of polymorphism and co-dominant inheritance, making it possible to directly assess heterozygosity levels. A major drawback is the effort needed to develop these markers for particular species. However, cross-species amplification enable microsatellite markers developed in one species to be transferred to related species. Fifteen microsatellite markers were developed from $T$. platyphyllos, which were subsequently tested in 23 Tilia species (Phuekvilai and Wolff, 2013).

Given the broad range of environmental and ecological conditions that $T$. cordata currently occupies, the ecological importance and silvicultural interest in this species will increase in the future, particularly in Northern Europe. The aim of this study was to assess the genetic diversity and differentiation of Latvian $T$. cordata populations using nuclear microsatellite markers.

\section{MATERIALS AND METHODS}

Analysed populations and sample collection. Samples for DNA extraction were collected from $28 T$. cordata plots located throughout the territory of Latvia (Fig. 1, Table 1). Leaf or twig samples were collected from 24 to 30 individuals from each plot. A total of 784 individuals were collected from 28 populations.

DNA extraction and genotyping. DNA was extracted using a modified CTAB method (Doyle and Doyle, 1990). The 15 microsatellite markers developed specifically for the genus Tilia (Tc4, Tc5, Tc6, Tc7, Tc8, Tc11, Tc31, Tc915, Tc918, Tc920, Тc927, Тc937, Тc943, Тc951 and Tc963) (Phuekvilai and Wolff, 2013) were tested on 16 randomly chosen individuals from different populations of T. cordata. PCR reactions were performed in a volume of $10 \mu \mathrm{l}$ containing approximately $50 \mathrm{ng}$ DNA, $2 \mu \mathrm{l} \mathrm{HOT} \mathrm{FIREPol}{ }^{\circledR}$ Blend Master Mix (Solis BioDyne) (containing $10 \mathrm{mM}$ $\mathrm{MgCl}_{2}$ ), $0.3 \mu \mathrm{M}$ forward and reverse primers. PCR was carried out in a thermocycler (Eppendorf Mastercycler epgradient) using the following protocol: initial predenaturation step at $95{ }^{\circ} \mathrm{C}$ for $5 \mathrm{~min}$, followed by 15 cycles of $95^{\circ} \mathrm{C}$ for $15 \mathrm{~s}, 54{ }^{\circ} \mathrm{C}$ for $15 \mathrm{~s}$, and $72{ }^{\circ} \mathrm{C}$ for $15 \mathrm{~s}$, and 20 cycles of

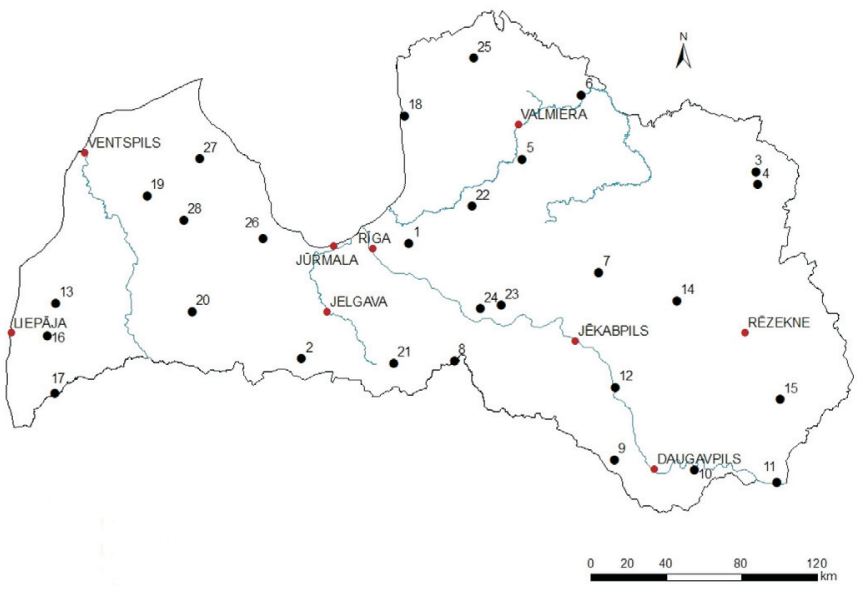

Fig. 1. Analysed T. cordata populations in Latvia (black dots - site numbering as in Table 1).

$89{ }^{\circ} \mathrm{C}$ for $20 \mathrm{~s}, 52{ }^{\circ} \mathrm{C}$ for $20 \mathrm{~s}, 72{ }^{\circ} \mathrm{C}$ for $20 \mathrm{~s}$, and a final extension step of $72{ }^{\circ} \mathrm{C}$ for $30 \mathrm{~min}$.

All PCR reaction products were diluted $1: 10$ with deionised water, and visualised on an Applied Biosystems ABI Prism 3100xl Genetic Analyser. Genotyping was performed using GeneMapper 4.0 (Applied Biosystems).

After marker testing, Tc8 was discarded as it was monomorphic, and Tc918 was discarded as there was no amplification. Marker Tc7 amplified more than two alleles within individuals, and was subsequently analysed on all individuals, and was genotyped as representing two loci. Therefore, the entire sample set of 784 individuals was genotyped at 14 loci.

Micro-Checker 2.2 (Van Oosterhout et al., 2004) was used to identify potential null alleles. GenAlEx 6.501 (Peakall and Smouse 2012) was used to calculate genetic diversity indices, and AMOVA and pairwise population differentiation $\left(\mathrm{F}_{\mathrm{ST}}\right)$ (using 999 permutations). CERVUS software was used to identify duplicated genotypes (Kalinowski et al., 2007), using a minimum of 12 loci needed for a match, and 1 mismatching locus allowed. STRUCTURE 2.3.4 was used to determine clustering of the populations using a 50000 burnin period, followed by 75000 MCMC steps. K was determined for 1 to 28 with 10 runs for each value of $\mathrm{K}$. The LOCPRIOR model was applied, using the sampling location as default information to assist clustering, which is recommended for use with datasets with weak structure signal (Pritchard et al., 2000). The optimal value of $\mathrm{K}$ was determined using the $\Delta \mathrm{K}$ method (Evanno et al., 2005) using STRUCTURE HARVESTER (Earl, 2012). Coefficients of membership to the most likely $\mathrm{K}$ cluster number were visualised using Distruct via the CLUMPAK server (Kopelman et al., 2015).

\section{RESULTS}

The presence of potential null alleles was assessed using Micro-Checker 2.2. Potential null alleles were identified at 9 of the 14 loci, and in most cases, these potential null al- 
Table 1. Locations and site descriptions of, and anthropogenic impact on, analysed T. cordata populations

\begin{tabular}{|c|c|c|c|c|c|c|c|}
\hline \multirow{2}{*}{$\begin{array}{l}\text { Pop. } \\
\text { No. }\end{array}$} & \multirow[t]{2}{*}{ Pop. name } & \multicolumn{2}{|c|}{ Coordinates, LKS-92 } & \multirow[t]{2}{*}{ Municipality } & \multirow[t]{2}{*}{ Region } & \multirow[t]{2}{*}{ Site description } & \multirow{2}{*}{$\begin{array}{c}\text { Anthopogenic } \\
\text { impact }\end{array}$} \\
\hline & & $\mathrm{X}$ & $\mathrm{Y}$ & & & & \\
\hline 1 & Nāgelmuiža & 527032 & 6315375 & Ropažu & Eastern & Park & High \\
\hline 2 & Ziedkalne & 470090 & 6254354 & Tērvetes & Western & T. cordata stand & Low \\
\hline 3 & Kuprava & 711009 & 6353573 & Alūksnes & Eastern & T. cordata stand & Low \\
\hline 4 & Irikava & 711998 & 6346607 & Viḷakas & Eastern & T. cordata stand & Low \\
\hline 6 & Saule & 618522 & 6394155 & Valkas & Eastern & Floodplain broadleaf forest & Low \\
\hline 7 & Kābeḷkalns & 627670 & 6300090 & Ikšķiles & Eastern & Castle mound & High \\
\hline 8 & Kurmene & 551082 & 6253115 & Aizkraukles & Eastern & Park & High \\
\hline 9 & Rauda & 635957 & 6200558 & Daugavpils & Eastern & Broadleaf forest & Low \\
\hline 10 & Lazdukalns & 678471 & 6195196 & Daugavpils & Eastern & Broadleaf forest & Low \\
\hline 12 & Jersika & 636250 & 6238950 & Lìvānu & Eastern & Castle mound & High \\
\hline 13 & Dunalka & 339455 & 6283570 & Aizputes & Western & Park & High \\
\hline 14 & Salenieki & 669018 & 6285148 & Varakḷānu & Eastern & Broadleaf forest & Low \\
\hline 15 & Pilori & 723831 & 6232751 & Dagdas & Eastern & Broadleaf forest & Low \\
\hline 16 & Gavieze & 335390 & 6266410 & Grobinas & Western & Broadleaf forest & Low \\
\hline 17 & Lukna & 339041 & 6235847 & Bārtas & Western & Broadleaf forest & Low \\
\hline 18 & Oltūži & 524610 & 6383120 & Salacgrīvas & Western & Broadleaf forest & Medium \\
\hline 19 & Moricsala & 388000 & 6340600 & Ventspils & Western & Broadleaf forest & Low \\
\hline 20 & Ciecere & 412174 & 6279352 & Brocēnu & Western & Broadleaf forest & Low \\
\hline 21 & Lejnieki & 518920 & 6251880 & Bauskas & Western & Cemetery & High \\
\hline 22 & Krimulda & 560440 & 6335120 & Siguldas & Eastern & Pine-broadleaf forest & Medium \\
\hline 25 & Mazsalaca & 561480 & 6413700 & Mazsalacas & Eastern & Mixed forest & High \\
\hline 26 & Tukums & 449432 & 6318047 & Tukuma & Western & Mixed forest & Low \\
\hline 27 & Valdemārpils & 416137 & 6360284 & Talsu & Western & Park & High \\
\hline 28 & Veǵi & 407735 & 6327879 & Sabiles & Western & Broadleaf forest & Low \\
\hline
\end{tabular}

leles were found in only one to four populations. Potential null alleles at three loci (Tc4, Tc11 and Tc31) were identified in 14, 11, and 17 populations, respectively. However, as a total of 28 populations were analysed, all loci were retained for further analysis.

The genetic diversity parameters of the analysed loci are summarised in Table 2. The total number of alleles at each locus ranged from two (Tc11) to 31 (Tc963), while the average number of alleles (over all populations) at each locus ranged from two (Tc11) to 13.25 (Tc963). The fixation index or inbreeding coefficient $(\mathrm{F})$ was close to zero for most loci, with the exception of Tc4, Tc11 and Tc31, which were all positive. However, as mentioned previously, this heterozygote excess (indicating the potential presence of null alleles) at these loci was not detected in all populations, and so all loci were retained for analyses.

The genetic diversity parameters of the analysed populations are summarised in Table 3. The average number of alleles (over all loci) ranged from 4.43 (Salenieki) to 7.14 (Nāgelmuiža). The Salenieki population also had the lowest values for number of effective alleles $(\mathrm{Ne})$ and information index (I). However, the Skriveri population had the highest $\mathrm{Ne}$ and I values, indicating that the allele frequencies were more evenly distributed in this population compared to Nāgelmuiža. The fixation index (F) ranged from -0.07 (Aizkraukle) to 0.20 (Nāgelmuiža). However, most populations had $\mathrm{F}$ values close to zero, with only five populations (Saule, Nāgelmuiža, Lupandi, Moricsala and Oltūži) having $\mathrm{F}$ values above 0.10 .

A total of 244 individuals with identical matching multilocus genotypes (MMGs) were found in all analysed populations except for Ciecere and Lukna. All individuals with MMGs were identified within populations, indicating that this was a result of vegetative reproduction, rather than a lack of discriminating power of the utilised markers. This indicates that $31 \%$ of the analysed individuals were propagated vegetatively. A total of 106 groups of individuals with MMGs were identified, with the number of individuals in each group ranging from 2 to 21 (average 9.4). The populations with the highest number of MMG groups were Aizkraukle and Tukums, which had a total of ten groups 
Table 2. Genetic diversity parameters of the analysed loci

\begin{tabular}{|c|c|c|c|c|c|c|c|c|c|c|c|c|c|c|}
\hline & $\mathrm{Tc} 4$ & Tc5 & Tc6 & Tc7 & Tc11 & Tc937 & Tc7_1 & Tc920 & Tc951 & Tc943 & Tc31 & Тc963 & Tc915 & Tc927 \\
\hline Ntot & 11 & 17 & 15 & 11 & 2 & 10 & 3 & 12 & 4 & 4 & 9 & 31 & 16 & 3 \\
\hline $\mathrm{Na}$ & $\begin{array}{c}7.04 \\
(0.25)\end{array}$ & $\begin{array}{c}6.50 \\
(0.30)\end{array}$ & $\begin{array}{c}7.57 \\
(0.32)\end{array}$ & $\begin{array}{c}6.54 \\
(0.18)\end{array}$ & $\begin{array}{c}2.00 \\
(0.00)\end{array}$ & $\begin{array}{c}4.89 \\
(0.21)\end{array}$ & $\begin{array}{c}2.50 \\
(0.10)\end{array}$ & $\begin{array}{c}7.96 \\
(0.18)\end{array}$ & $\begin{array}{c}3.36 \\
(0.11)\end{array}$ & $\begin{array}{c}2.64 \\
(0.12)\end{array}$ & $\begin{array}{c}4.32 \\
(0.22)\end{array}$ & $\begin{array}{l}13.25 \\
(0.66)\end{array}$ & $\begin{array}{c}8.61 \\
(0.36)\end{array}$ & $\begin{array}{c}2.43 \\
(0.11)\end{array}$ \\
\hline $\mathrm{Ne}$ & $\begin{array}{c}4.47 \\
(0.21)\end{array}$ & $\begin{array}{c}3.22 \\
(0.14)\end{array}$ & $\begin{array}{c}4.17 \\
(0.20)\end{array}$ & $\begin{array}{c}3.79 \\
(0.15)\end{array}$ & $\begin{array}{c}1.74 \\
(0.04)\end{array}$ & $\begin{array}{c}2.18 \\
(0.12)\end{array}$ & $\begin{array}{c}1.74 \\
(0.04)\end{array}$ & $\begin{array}{c}4.63 \\
(0.21)\end{array}$ & $\begin{array}{c}2.19 \\
(0.06)\end{array}$ & $\begin{array}{c}1.95 \\
(0.06)\end{array}$ & $\begin{array}{c}2.00 \\
(0.10)\end{array}$ & $\begin{array}{c}7.40 \\
(0.50)\end{array}$ & $\begin{array}{c}4.03 \\
(0.21)\end{array}$ & $\begin{array}{c}1.23 \\
(0.04)\end{array}$ \\
\hline Ho & $\begin{array}{c}0.63 \\
(0.03)\end{array}$ & $\begin{array}{c}0.69 \\
(0.02)\end{array}$ & $\begin{array}{c}0.79 \\
(0.02)\end{array}$ & $\begin{array}{c}0.75 \\
(0.02)\end{array}$ & $\begin{array}{c}0.26 \\
(0.03)\end{array}$ & $\begin{array}{c}0.54 \\
(0.03)\end{array}$ & $\begin{array}{c}0.42 \\
(0.02)\end{array}$ & $\begin{array}{c}0.78 \\
(0.02)\end{array}$ & $\begin{array}{c}0.50 \\
(0.02)\end{array}$ & $\begin{array}{c}0.53 \\
(0.03)\end{array}$ & $\begin{array}{c}0.28 \\
(0.02)\end{array}$ & $\begin{array}{c}0.82 \\
(0.04)\end{array}$ & $\begin{array}{c}0.72 \\
(0.02)\end{array}$ & $\begin{array}{c}0.16 \\
(0.02)\end{array}$ \\
\hline $\mathrm{uHe}$ & $\begin{array}{c}0.78 \\
(0.01)\end{array}$ & $\begin{array}{c}0.68 \\
(0.02)\end{array}$ & $\begin{array}{c}0.76 \\
(0.01)\end{array}$ & $\begin{array}{c}0.74 \\
(0.01)\end{array}$ & $\begin{array}{c}0.42 \\
(0.02)\end{array}$ & $\begin{array}{c}0.52 \\
(0.02)\end{array}$ & $\begin{array}{c}0.42 \\
(0.02)\end{array}$ & $\begin{array}{c}0.79 \\
(0.01)\end{array}$ & $\begin{array}{c}0.54 \\
(0.01)\end{array}$ & $\begin{array}{c}0.48 \\
(0.02)\end{array}$ & $\begin{array}{c}0.48 \\
(0.03)\end{array}$ & $\begin{array}{c}0.83 \\
(0.03)\end{array}$ & $\begin{array}{c}0.75 \\
(0.02)\end{array}$ & $\begin{array}{c}0.17 \\
(0.02)\end{array}$ \\
\hline $\mathrm{F}$ & $\begin{array}{c}0.17 \\
(0.04)\end{array}$ & $\begin{array}{l}-0.03 \\
(0.03)\end{array}$ & $\begin{array}{l}-0.07 \\
(0.02)\end{array}$ & $\begin{array}{l}-0.04 \\
(0.02)\end{array}$ & $\begin{array}{c}0.36 \\
(0.06)\end{array}$ & $\begin{array}{l}-0.07 \\
(0.03)\end{array}$ & $\begin{array}{l}-0.02 \\
(0.03)\end{array}$ & $\begin{array}{l}-0.01 \\
(0.02)\end{array}$ & $\begin{array}{c}0.05 \\
(0.04)\end{array}$ & $\begin{array}{c}-0.1 \\
(0.05)\end{array}$ & $\begin{array}{c}0.38 \\
(0.05)\end{array}$ & $\begin{array}{l}-0.01 \\
(0.02)\end{array}$ & $\begin{array}{c}0.02 \\
(0.02)\end{array}$ & $\begin{array}{c}0.02 \\
(0.04)\end{array}$ \\
\hline
\end{tabular}

Natot, total number of alleles; Na, average number of alleles over all loci; Ne, average number of effective alleles over all loci; I, average information index over all loci; Ho, average observed heterozygosity over all loci; uHe, average unbiased expected heterozygosity over all loci; F, average inbreeding coefficient over all loci

Table 3. Genetic diversity parameters of the analysed populations (average values over all analysed loci)

\begin{tabular}{|c|c|c|c|c|c|c|}
\hline & $\mathrm{Na}$ & $\mathrm{Ne}$ & I & Ho & $\mathrm{uHe}$ & $\mathrm{F}$ \\
\hline Saule & $5.86(0.94)$ & $3.13(0.40)$ & $1.22(0.15)$ & $0.51(0.07)$ & $0.61(0.06)$ & $0.14(0.08)$ \\
\hline Ziedkalne & $5.93(1.01)$ & $3.45(0.64)$ & $1.21(0.18)$ & $0.58(0.07)$ & $0.58(0.07)$ & $-0.01(0.05)$ \\
\hline Nāgelmuiža & $7.14(1.16)$ & $3.33(0.45)$ & $1.33(0.17)$ & $0.51(0.07)$ & $0.62(0.06)$ & $0.20(0.05)$ \\
\hline Mazā Ellīte & $5.36(0.92)$ & $3.30(0.58)$ & $1.15(0.18)$ & $0.57(0.08)$ & $0.58(0.07)$ & $0.01(0.07)$ \\
\hline Kuprava & $4.71(0.59)$ & $2.82(0.35)$ & $1.10(0.13)$ & $0.61(0.07)$ & $0.58(0.05)$ & $-0.07(0.06)$ \\
\hline Irikava & $5.71(0.85)$ & $3.35(0.50)$ & $1.24(0.15)$ & $0.56(0.06)$ & $0.63(0.06)$ & $0.07(0.06)$ \\
\hline Kābeḷkalns & $5.00(0.72)$ & $2.96(0.45)$ & $1.11(0.14)$ & $0.54(0.08)$ & $0.58(0.05)$ & $0.09(0.09)$ \\
\hline Lazdukalns & $6.14(0.99)$ & $3.35(0.62)$ & $1.23(0.17)$ & $0.56(0.06)$ & $0.60(0.06)$ & $0.04(0.07)$ \\
\hline Jersika & $4.93(0.73)$ & $2.65(0.39)$ & $1.05(0.13)$ & $0.53(0.07)$ & $0.55(0.06)$ & $0.02(0.06)$ \\
\hline Lupandi & $5.00(0.66)$ & $2.58(0.33)$ & $1.03(0.13)$ & $0.46(0.07)$ & $0.54(0.06)$ & $0.13(0.07)$ \\
\hline Rauda & $5.57(0.84)$ & $3.11(0.46)$ & $1.19(0.15)$ & $0.60(0.06)$ & $0.61(0.05)$ & $0.02(0.08)$ \\
\hline Pilori & $5.57(1.04)$ & $3.15(0.64)$ & $1.16(0.16)$ & $0.55(0.06)$ & $0.58(0.06)$ & $0.04(0.06)$ \\
\hline Salenieki & $4.43(0.58)$ & $2.52(0.26)$ & $1.02(0.13)$ & $0.56(0.07)$ & $0.55(0.06)$ & $-0.05(0.08)$ \\
\hline Krimulda & $6.07(0.98)$ & $3.51(0.66)$ & $1.27(0.16)$ & $0.59(0.06)$ & $0.62(0.06)$ & $0.03(0.03)$ \\
\hline Skrīveri & $6.21(1.03)$ & $4.05(0.78)$ & $1.34(0.18)$ & $0.64(0.06)$ & $0.65(0.06)$ & $-0.01(0.05)$ \\
\hline Veği & $5.43(0.86)$ & $3.00(0.38)$ & $1.16(0.14)$ & $0.60(0.07)$ & $0.59(0.05)$ & $0.01(0.06)$ \\
\hline Ciecere & $5.79(0.87)$ & $3.24(0.45)$ & $1.25(0.14)$ & $0.58(0.06)$ & $0.63(0.04)$ & $0.06(0.06)$ \\
\hline Moricsala & $6.21(1.16)$ & $3.32(0.54)$ & $1.22(0.18)$ & $0.51(0.08)$ & $0.59(0.06)$ & $0.15(0.08)$ \\
\hline Mazsalaca & $5.57(0.98)$ & $3.28(0.56)$ & $1.19(0.17)$ & $0.56(0.07)$ & $0.60(0.06)$ & $0.06(0.07)$ \\
\hline Lejnieki & $4.71(0.79)$ & $2.59(0.29)$ & $1.04(0.12)$ & $0.58(0.06)$ & $0.57(0.04)$ & $-0.03(0.07)$ \\
\hline Tukums & $6.14(1.01)$ & $3.36(0.54)$ & $1.23(0.17)$ & $0.56(0.06)$ & $0.60(0.06)$ & $0.06(0.03)$ \\
\hline Aizkraukle & $5.79(0.92)$ & $2.98(0.44)$ & $1.14(0.17)$ & $0.59(0.07)$ & $0.56(0.07)$ & $-0.07(0.05)$ \\
\hline Gavieze & $6.64(1.05)$ & $3.55(0.61)$ & $1.30(0.17)$ & $0.58(0.07)$ & $0.63(0.06)$ & $0.09(0.08)$ \\
\hline Dunalka & $5.57(0.86)$ & $3.53(0.52)$ & $1.30(0.14)$ & $0.63(0.06)$ & $0.66(0.04)$ & $0.05(0.05)$ \\
\hline Lukna & $6.07(1.03)$ & $3.58(0.61)$ & $1.27(0.16)$ & $0.59(0.06)$ & $0.64(0.05)$ & $0.07(0.07)$ \\
\hline Oltūži & $4.64(0.63)$ & $2.62(0.30)$ & $1.04(0.14)$ & $0.47(0.06)$ & $0.54(0.06)$ & $0.11(0.06)$ \\
\hline
\end{tabular}

$\mathrm{Na}$, number of alleles; Ne, number of effective alleles; I, information index; Ho, observed heterozygosity; uHe, unbiased expected heterozygosity; F, inbreeding coefficient 


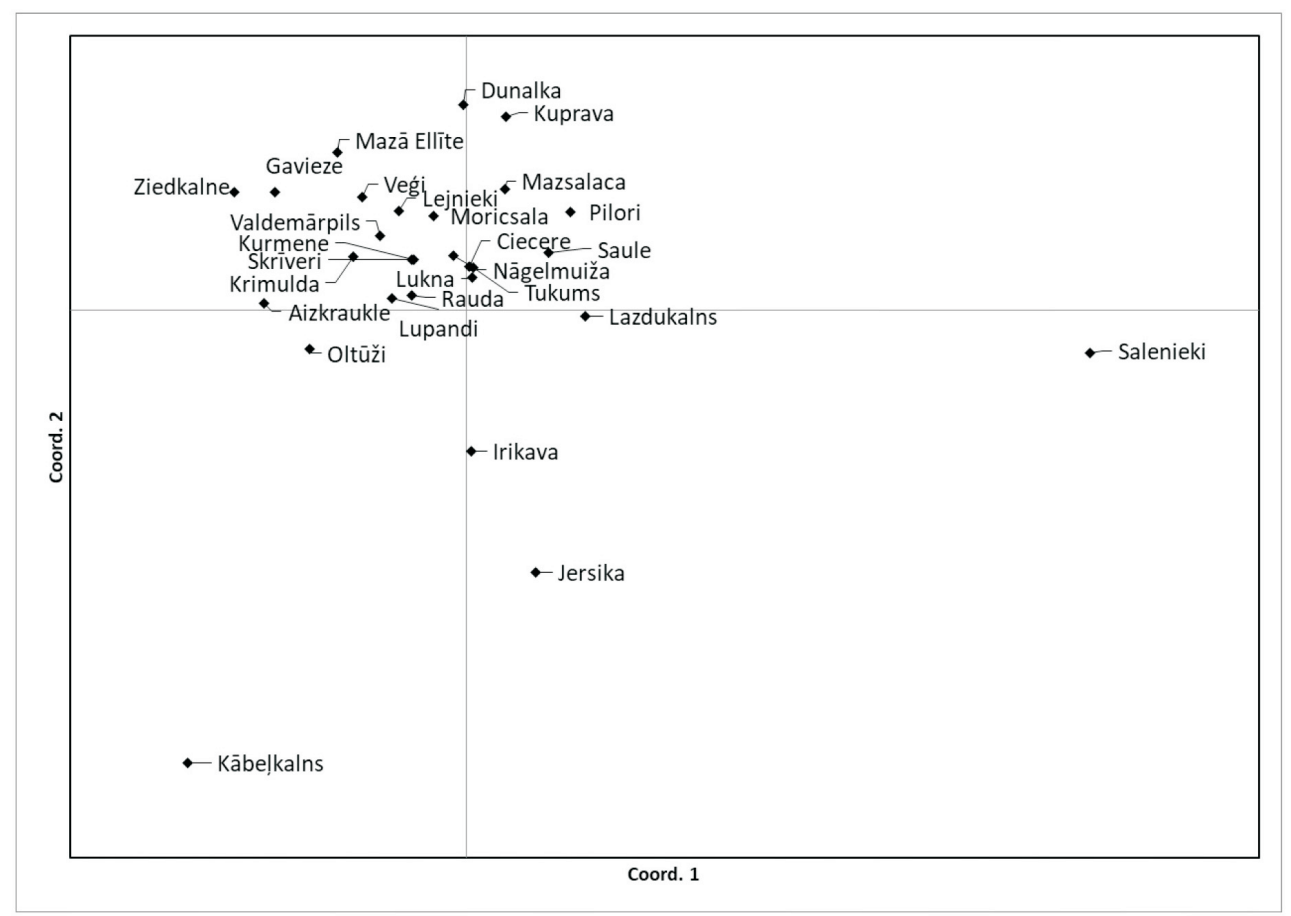

Fig. 2. PCoA of pairwise Nei genetic distances between analysed $T$. cordata populations. Percentage of variation explained by axis $1-37.62$, axis $2-$ 13.74 .

each, comprising of a total 18 and 19 individuals, respectively. Nine MMGs were identified in both Kuprava and Saule (comprising of a total of 21 and 17 individuals, respectively). Between one and seven MMG groups were identified in the remaining populations.

Unique alleles were found in ten populations (Mazā Ellìte, Lazdukalns, Jersika, Pilori, Krimulda, Veği, Valdemārpils, Gavieze, Dunalka, Oltūži), with frequencies ranging from 0.019 to 0.143 (average 0.063 ). Analysis of molecular variance (AMOVA) indicated that $6 \%$ of the genetic variation was between populations, and $94 \%$ within populations (Fst $=0.064, p<0.01)$. Pairwise Fst values ranged from 0.013 (Nāgelmuiža-Moricsala) to 0.129 (Salenieki-Oltūži). Pairwise Nei genetic distances were calculated, and were used to generate a PCoA plot (Fig. 2). Most of the samples representing analysed populations clustered together, with Kābellkalns, Irikava, Jersika and Salenieki being the most distinct. There was no evidence of higher order structure, either by region (Eastern and Western), or anthropogenic impact (high, medium, low), with AMOVA indicating that differentiation between these groups was low - Fst $=0.01(p<$ 0.01 ) in both cases. Mantel analysis of the pairwise genetic and geographic distance matrices showed a slightly positive correlation both at a population level $(\mathrm{Rxy}=0.092)$, which was not significant $(p>0.05)$, and at an individual level $(\mathrm{Rxy}=0.077)$, which was significant $(p<0.01)$.

Bayesian clustering was performed to indicate the population of origin of the analysed individuals. This assists clustering in sample sets with low differentiation. Using the $\Delta \mathrm{K}$ method (Evanno et al., 2005), the most likely number of clusters was 16 , but there were several additional peaks in the $\mathrm{K} / \Delta \mathrm{K}$ graph (Fig. 3) The coefficients of membership for $\mathrm{K}=16$, indicating the probability that an individual is assigned to a particular cluster, are presented in Figure 4.

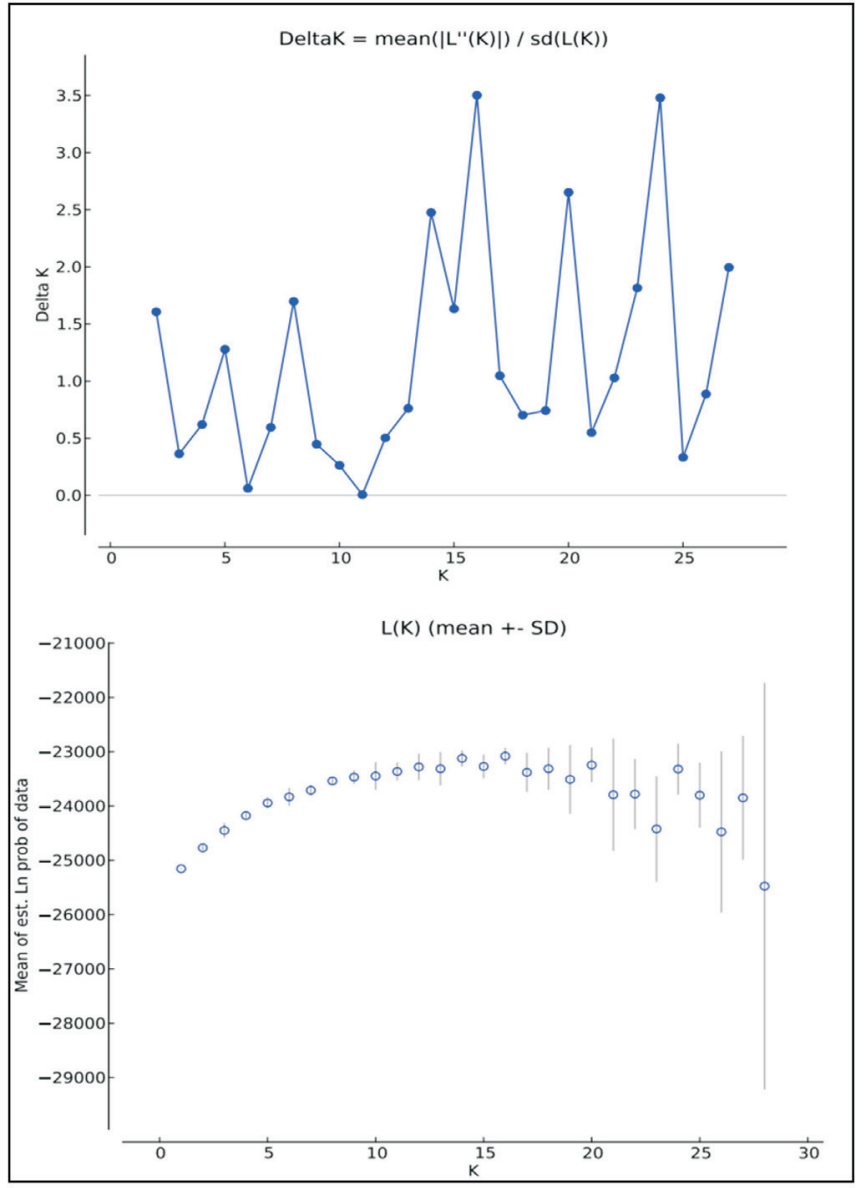

Fig. 3. DeltaK and mean $\mathrm{L}(\mathrm{K})$ plots for $\mathrm{K}$ values $1-28$.

\section{DISCUSSION}

The analysed Latvian $T$. cordata populations had low to moderate levels of genetic differentiation. The populations were sampled from throughout the territory of Latvia, and 


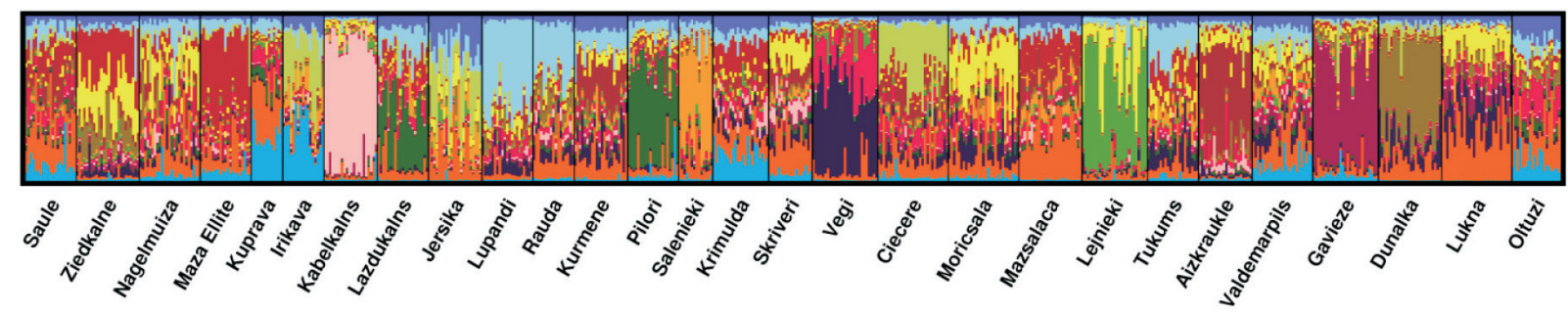

Fig. 4. Distract plots of coefficients of membership for $\mathrm{K}=16$, the most likely number of clusters as determined by the $\Delta \mathrm{K}$ method, indicating the probability that each analysed individual is attributed to the corresponding population inferred from STRUCTURE analysis.

had differing levels of anthropogenic impact, ranging from strictly protected areas (e.g. Moricsala) to populations from parks, cemeteries and planted stands. However, these differing conditions did not have a significant impact on the genetic clustering of the populations, or on other genetic diversity parameters. Populations with the highest or lowest diversity parameters were not differentiated by anthropogenic impact. There was no differentiation identified between the eastern and western regions, but there was a slightly positive correlation between genetic and geographic distances, indicating that isolation by distance may have some impact on the genetic structuring of Latvian $T$. cordata populations. However, no highly differentiated or inbred population was identified, indicating that there was sufficient gene flow, with no significant barriers identified. Vegetative reproduction was identified in most analysed populations, and almost $1 / 3^{\text {rd }}$ of analysed individuals were considered as being of clonal origin. This is a similar level of clonal reproduction as reported by other studies utilising DNA markers for the analysis of Tilia populations — in the UK, $25 \%$ of individuals were reported to be clonal (Logan et al., 2015). In Denmark, $48 \%$ of T. cordata individuals were clonal (Erichsen et al., 2019), but in that study, nine populations were sampled, and in some of the analysed populations, all individuals in a stand or section were sampled.

Genetic diversity parameters of Latvian $T$. cordata populations were similar to those reported in the UK (Logan et al., 2015), Denmark (Erichsen et al., 2019) and across Europe (Logan et al., 2019). Genetic differentiation of Latvian $T$. cordata populations was moderate (overall Fst was 0.064), which is close to that of Tilia populations in the UK (0.071) (Logan et al., 2015), but higher than reported for Danish populations (0.034) (Erichsen et al., 2019). Unique alleles were found in ten of the 28 Latvian populations, and while only a total of 13 unique alleles were identified, they had relatively high frequencies, ranging from 0.019 to 0.143 (average 0.063). This indicates some degree of isolation between populations; however gene flow does not seem to be substantially restricted within Latvia. Gene flow is expected to be lower to that of many other forest tree species due to Tilia being insect pollinated and with heavy and winddispersed seeds (Logan et al., 2019). Bayesian analysis indicated that the most probable number of clusters was 16 , supporting the hypothesis that the Latvian T. cordata populations are somewhat isolated from each other.

It was reported that clonality increased in range-edge $T$. cordata populations compared to central populations (Logan et al., 2019). Leading (northern) range-edge $T$. cordata populations were defined as occurring North of $54^{\circ} \mathrm{N}$, which includes the entire territory of Latvia $\left(55^{\circ} \mathrm{N}\right.$ to $\left.58^{\circ} \mathrm{N}\right)$. The relatively low levels of clonality found in Latvian populations could be related with the sampling method, as the represented populations were not sampled exhaustively, and individuals collected were spatially separated, which would reduce the number of clonal individuals sampled. $T$. cordata stands are not actively managed in Latvia (including coppicing), which also reduces flowering and thus increases the proportion of clonal reproduction (Waller et al., 2012). Previous reports that have not utilised DNA analyses to identify clones, have reported high levels of clonality (80\%) (Sakss, 1960; Chistyakova, 1982; Radoglou et al., 2009), which is probably a reflection of the lower discrimination and informativeness of morphological and observation data (Logan et al., 2019). Previous studies have reported that while clonal reproduction is important in $T$. cordata, sexual reproduction is still the most important mode of reproduction in the major part of the distribution range (Logan et al., 2019). Based on the results of this study, this also is applicable to Latvian $T$. cordata populations, and with an expected increase in temperature associated with climate change, seed production and sexual reproduction could be expected to increase.

In conclusion, the analysed Latvian $T$. cordata populations had high genetic diversity, and were not overly isolated from each other, with moderate gene flow between populations. No highly differentiated populations were identified. The results of this study can be used to identify stands with the highest genetic diversity, including rare or unique alleles, as well as to determine the most genetically differentiated populations. This information is crucial for potential future breeding efforts, as well as to effectively designate $T$. cordata genetic resource stands. $T$. cordata is productive under the current climatic and growth conditions in Latvia, and therefore this species has potential for use in forestry, as well as playing a significant role in maintaining biodiversity and other ecosystem services. 


\section{ACKNOWLEDGEMENTS}

This study was supported by the Latvian-Belorussian cooperation programme research agreement LV-BY/2019/1 "Characterisation of the Latvian and Belorussian smallleaved lime (Tilia cordata Mill) and Norway maple (Acer platanoides L.) genepool and utilisation to ensure sustainable forestry in changing climatic conditions" funded by the State Education Development Agency of the Republic of Latvia.

\section{REFERENCES}

Chistyakova, A. A. (1982). Biological pecularities of vegetation regeneration in main species of broad-leaved forests [Чистякова, А. А. Биологические особенности вегетативного возобнавления основных пород в широколиственных лесах]. Lesovedenie [Лесоведение], 2, 11-17 (in Russian).

Daugaviete, M., Lazdina, D., Celma, S., Daugavietis, U. (2019). Characteristic growing parameters of small-leaved lime and Norway maple stands in the climatic conditions of Latvia. Acta Biol. Univ. Daugavp., 19 (2), $115-128$.

De Jaegere, T., Hein, S., Claessens, H. (2016). A review of the characteristics of small-leaved lime (Tilia cordata Mill.) and their implications for silviculture in a changing climate. Forests, 7 (3), 56.

Doyle, J., Doyle, J. L. (1990). Isolation of plant DNA from fresh tissue. Focus, 12, 13-15.

Erichsen, E. O., Wolff, K., Hansen, O. K. (2019). Genetic and clonal structures of the tree species Tilia cordata Mill. in remnants of ancient forests in Denmark. Population Ecol., 61 (3), 243-255.

Evanno, G., Regnaut, S., Goudet, J. (2005). Detecting the number of clusters of individuals using the software STRUCTURE: A simulation study. Mol. Ecol., 14 (8), 2611-2620.

Fromm, M., Hattemer, H. H. (2003). Inheritance of allozymes and hybridization in two European Tilia species. Heredity, 91, 337-344.

Kalinowski, S. T., Taper, M. L., Marshall, T. C. (2007). Revising how the computer program CERVUS accommodates genotyping error increases success in paternity assignment. Mol. Ecol., 16, 1099-1006.

Kopelman, N. M., Mayzel, J., Jakobsson, M., Rosenberg, N. A., Mayrose, I. (2015). CLUMPAK: A program for identifying clustering modes and packaging population structure inferences across K. Mol. Ecol. Res., 15 (5), 1179-1191.

Received 23 December 2020

Accepted in the final form 3 August 2021
Liesebach, H., Sinkó, Z. (2008). A contribution to the systematics of the genus Tilia with respect to some hybrids by RAPD analysis. Dendrobiology, 59, 13-22.

Logan, S. A., Phuekvilai, P., Wolff, K. (2015). Ancient woodlands in the limelight: delineation and genetic structure of ancient woodland species Tilia cordata and Tilia platyphyllos (Tiliaceae) in the UK. Tree Genet. Genomes, 11 (3), 52.

Logan, S. A., Phuekvilai, P., Sanderson, R., Wolff, K. (2019). Reproductive and population genetic characteristics of leading-edge and central populations of two temperate forest tree species and implications for range expansion. Forest Ecol. Manag., 433, 475-486.

Maurer, W. D., Tabel, U. (1995). A methodological study to improve isozyme analysis for identification of clones of Tilia (Linden syn. Lime tree). Silvae Genetica 44, 351-356.

Peakall, R., Smouse, P. E. (2012). GenAlEx 6.5: Genetic analysis in Excel. Population genetic software for teaching and research - an update. Bioinformatics, 28, 2537-2539.

Pigott, C. D., Huntley, J. P. (1978). Factors controlling the distribution of Tilia cordata at the northern limits of its geographical range. I. Distribution in North-West England. New Phytol., 81, 429-441.

Pigott, C. D., Huntley, J. P. (1980). Factors controlling the distribution of Tilia cordata at the northern limits of its geographical range. II. History in North-West England. New Phytol., 84, 145-164.

Phuekvilai, P., Wolff, K. (2013). Characterization of microsatellite loci in Tilia platyphyllos (Malvaceae) and cross-amplification in related species. Applications in Plant Sciences, 1 (4), apps.1200386.

Pritchard, J. K., Stephens, M., Donnelly, P. (2000). Inference of population structure using multilocus genotype data. Genetics, 155, 945-959.

Radoglou, K., Dobrowolska, D., Spyroglou, G., Nicolescu, V. N. (2009). A review on the ecology and silviculture of limes (Tilia cordata Mill., Tilia platyphyllos Scop. and Tilia tomentosa Moench.) in Europe. Die Bodenkultur, 60 (3), 9-20.

Sakss, K. (1960). Small-leaved lime in Latvian forests [Liepa Latvijas PSR mežos]. Proceedings of the Institute of Forestry Problems and the Institute of Wood Chemistry. Forestry issues [Mežsaimniecības problēmu institūta un Koksnes k̦īmijas institūta raksti. Mežsaimniecības jautājumi], 20, 3-34 (in Latvian).

Van Oosterhout, C., Hutchinson, W. F., Wills, D. P., Shipley, P. (2004). MICRO-CHECKER: software for identifying and correcting genotyping errors in microsatellite data. Molecular Ecology Notes, 4, 535-538.

Waller, M., Grant, M. J., Bunting, M. J. (2012). Modern pollen studies from coppiced woodlands and their implications for the detection of woodland management in Holocene pollen records. Rev. Palaeobot. Palynol., 187, $11-28$.

\section{LATVIJAS TILIA CORDATA POPULĀCIJU GENĒTISKĀ DAUDZVEIDĪBA UN STRUKTŪRA}

Mainīgie klimatiskie apstākḷi maina platlapju koku sugu ekoloğisko un mežkopības nozīmi Ziemeḷeiropā. Parastā liepa (Tilia cordata Mill.) ir sastopama lielākajā dạ̄ā Eiropas, un ir bieži sastopama platlapju koku suga Latvijā. T. cordata spēj pielāgoties dažādiem vides un ekoloǵiskajiem apstākḷiem, tādiem kā temperatūra, ūdens pieejamība, augsnes veidi. Šì pētījuma mērḳis bija novērtēt Tilia cordata ǵenētisko daudzveidību un diferenciāciju Latvijas populācijās, izmantojot kodola mikrosatelīta marķierus. T. cordata Latvijas populācijās novērota augsta ġenētiskā daudzveidība, un tās nebija īpaši izolētas viena no otras, ar mērenu gēnu plūsmu starp populācijām. Augsti diferencētas populācijas netika identificētas. Veǵetatīvā reprodukcija tika identificēta lielākajā dậ̄ā analizēto populāciju, un gandrīz 1/3 no analizētajiem indivīdiem bija klonālas izcelsmes. T. cordata ir produktīva pašreizējos Latvijas klimatiskajos un augšanas apstākl,os, un tāpēc šai sugai ir potenciāls tikt izmantotai mežsaimniecībā, kā arī tai ir nozīmīga loma bioloğiskās daudzveidības un citu ekosistēmas pakalpojumu uzturēšanā. 